\title{
Rhizomic Identity, Performative Identity, In-Becoming Identity of the Characters in Maryse Condé's Narratives
}

\author{
Marie-Dominique Boyce \\ Fairfield University, Fairfield, CT, 06824, USA
}

\begin{abstract}
In Western culture, the symbol of the tree which divides into branches and has a foliage of the same lineage as its roots is the best symbol for describing identity and also for describing the Cartesian reasoning which proceeds by eliminating misconceptions and following thesingle true idea. In the West Indies culture, it is the rhizome that is the best symbol to describe the identity of these peoples. The rhizome as explained by Deleuze and Gattari in their Introduction Rhizome of the book A thousand plateaus, is a tuber that makes roots after being cut off from its original plant. In this respect, it is most appropriate to describe the people of the Caribbean who have been cut off from their African roots by slavery but who have thrived on the island, re-establishing links with the different peoples who came to work there. The rhizome is similar to the mangrove that protects the island from marine erosion, it intertwines with other plants so that it is impossible to distinguish the source plant. In this respect, it is the best symbol to describe the creole identity and the refusal of the West Indians to return to a racial and social system that promulgated the white race as superior to the black race during colonialism. The structure of the books of Maryse Condé is itself rhizomatic since it does not present the theme of its stories through the view point of an omnipotent author but through the view points of all the characters of the novel who by their discussions letthe reader discover their terrible history of slavery, and transform himinto a new man who would seek diversity.
\end{abstract}

Keywords: identity, rhizome, mangrove, slavery, creolity, de-territorialization, re-territorialization

\section{Introduction: Identity Represented As a Tree in Western Civilizations Versus the Rhizome in Caribbean Civilizations}

In Western culture, our Cartesian mind makes us analyze everything following a True/False binary logic. From this True/False dichotomy, we progress in our ideas by choosing the orientation of the single, true idea, the Truth.

In language, we also think that there is only one signifier, phoneme, to express a single signified, concept. In religion, humanity is believed to flow from the one divine source. Our existence and knowledge are only resurgences or mirrors of the primordial Root, God. Everything is brought back to the One, the Origin and is represented in Western culture by the metaphor of the tree, of the original root and trunk, which divide into family branches of the same lineage like the root.

Marie-Dominique Boyce, Ph.D., Adjunct Professor, Fairfield University, Fairfield, CT, 06824, USA. 
In Oriental or Caribbean culture, the generational principle of ideas is not binary. It is multiple. This is why the symbol of the rhizome is the best suited to describe the Caribbean identity, the uprooted identity from native Africa by slavery, but identity that still survives and has adapted to its new soil by doing like the rhizome, by venturing elsewhere, connecting with others and drawing its vitality from these encounters and this interbreeding.

This article will endeavor to demonstrate how the image of the rhizome, as presented by the linguists and psychologists Deleuze and Guattari in Mille Plateaus, is the best adapted to show the richness of the Caribbean identity as it is portrayed by the characters of Crossing the Mangrove and The Mixed Country by Maryse Condé.

Then, I will study the rhizomic structure of the books by Maryse Condé and demonstrate that these books do not have a theme defined in advance by an omnipotent author-genitor but that the story is woven as each character proposes his vision of the world. The story is not defined in advance, a "fatum", but it is a construction made in the present of the reading of the book between author-character and the reader, in which each person is in the same way an interlocutor to the dialogue of the text.

\section{Western Civilizations: Historical/Ancestral Lineage}

The Western model of the tree which plunges its roots in the fertile land and derives its substance, vigor and durability from it, is a theme dear to Western civilizations who see it as a foundation and a peculiarity in their identities, all different from the others by the origin of the peoples who have conquered and enslaved them, and who have imposed their identities and civilizations on them.

This connection with the history of a country and a civilization is a theme that has haunted Aimé Césaire. Wanting to copy the West Indian genealogy on that of the Western world, he even advocated returning to African roots and assimilation to France when the latter had been the colonial power who had enslaved the West Indies.

The lack of territorial historical roots is also what Maryse Condé felt and has expressed in her autobiography of her youth Le Coeur à Rire et à Pleurer (The Heart to Laugh and to Cry) (1999) when she wrote she was surprised to know no author of Guadeloupe when her high school teacher asked her to do a presentation on this subject and she expressed her envy of her Haitian comrades, who, they, had a country: "Ah, to be born in a real country, and independent country, and not in a krazur of departmental land! To fight for a national power! To possess a presidential palace with a president in a richly colored uniform!” (Condé, 1999, p. 153) [my translation $]^{1}$.

It is because of Guadeloupe's inability of becoming independent from France and because of its fear of loosing its identity in the globalization that Maryse Condé goes to Africa (Guinea, Ghana, Senegal) and marries a Guinean actor, Mamadou Condé. It was after this African experience, her divorce from Mamadou Condé and her return to Guadeloupe that she wrote her collection of short stories The Mixed Country (1997) and her novel Crossing the Mangrove (1989). She then understands, as Edouard Glissant had experienced before, that there is no return back to Africa. The journey of the slave boats, which brought the slaves to the West Indies cannot be reversed. African roots are cut off. Maryse Condé can no longer reintegrate into Africa and she also understands that, beyond the color of the skin, there is a Caribbean identity that contributes to her rejection by the Africans.

\footnotetext{
1 “Ah, être née dans un vrai pays, un pays indépendant, et non dans un krazur de terre départementale! Se battre pour un pouvoir national! Posséder un palais présidentiel avec un président en habit chamarré!” (Condé, 1999, p. 153).
} 


\section{Caribbean Civilizations: Transplanted, Vivacious Rhizome}

This Caribbean identity is comparable to the rhizome, which has all the energy it needs to survive/live. It is true that the West Indian people were severed from their roots, mixed in the holds of the slave ships, where people of different tribes were chained together so that they could not understand each other and unite against their oppressors. But these Caribbean people, disconnected from their origins and their maternal language nevertheless set foot on the island. Like the sugar cane rhizome that the African slave people helped grow on the island, these men and women prospered on the island while the ancient native forests of the island were uprooted and the ancient populations of the island decimated.

In the novel Crossing the Mangrove by Maryse Condé, we see that no individual is native to the island. All were either transplanted to the island during slavery, or transplanted themselves, cutting themselves off from their oppressive families. For the two most prosperous families of the island, the Lameaulnes and the Ramsaran families, the ideology of equality of the post-slavery generation is at the basis of the separation of the young from their families of origin. For the ancestor Gabriel Lameaulnes, a béké, (a white man) from Martinique, it is the refusal of marrying a person of his own race imposed by his family who led him to Guadeloupe and marry the Negress of his dreams in the years 1904-1905. Joby, the ancestor's grandson, tenderly remembers the picture of this mixed couple: “He is wearing spectacles and a musketeer's mustache. She's got a pleated madras kerchief and a thick choker” (Condé, 1989, p. 106) [my translation] ${ }^{2}$. As for the Ramsaran of Indian origin, their ancestors probably came on board the Aurélie ship when the abolition of slavery left the French planters with no labor power. These Indians from Francophone Indochina offered their workmanship for low salaries. This may account for Titor's father holding so dearly onto his sugar cane fields and not wanting to give any part of it to Titor when an adult. Titor had a fight with his father, which forced him to self-exile in this lost corner of Rivière au Sel in Guadeloupe.

For other people, the oppression of the political or capitalist society forced them to come into this place. Emmanuel Pélagie, a Forestry engineer, had to immigrate from the capital La Pointe with his young wife Dodose Pélagie, because of his involvement in anti-colonial demonstrations and of his subsequent transfer to the Research Center in Rivière au Sel. For Sonson, the father of Moses the postman, the military situation of appeal of the young men to fight in the Second World War compelled him to pretend to go to the Dissidence then made him change and spend his days in Jamaica with a Chinese woman Shawn. He then returned to Guadeloupe with his Chinese wife and child Moses, half negro half Chineseto the surprise of the whole family who thought he had died in the war.

\section{Adaptability of the Rhizome/Survival and Prosperity of the Caribbean People}

The rhizome is the appropriate symbol to show how Guadeloupe families could be broken, cut off from their roots but brought back together, following other trajectories and being re-stratified and re-territorialized. The families described in the novel Crossing the Mangrove seem indestructible in their totality, always finding the means to adapt to their new environment. The ancestor Lameaulnes is the one who first saw that the days of sugarcane after the abolition of slavery were gone, and created “the Nursery Lameaulnes”. And this ancestor's

\footnotetext{
2 “Lui, avec ses lunettes et ses moustaches à la d’Artagnan. Elle, avec son madras calendé et son gros collier chou” (Condé, 1989, p. 106).
} 
son Loulou, takes pride in the family's business: "Soon there will be the Single European Market and I shall sell my flowers as far away as England. Yes, my flowers will decorate the table of the Queen of England. Her Majesty, the Queen. I’ve already got my slogan: 'The Lameaulnes Nurseries: an earthly paradise for flowers'” (Condé, 1989, p. 109) [my translation] $]^{3}$.

Lameaulnes's son, Aristide also knows where is the profit and he stands up to his father explaining his idea to convert the savannah into fields of orchids and rare plants and make a garden to be visited by tourists.

In the case of the Ramsaran family, Rodrigue, the son of the ancestor Ramsaran, took advantage of the bankruptcy of the Farjol sugar factory to expand his estate and convert it into banana plantations. Later, his grandson Carmélien reconverted the tanks into crayfish ponds and made a prosperous trade with the hotels for tourists of the whole island.

\section{Hybridization of the Rhizome/Métissage of the Caribbean People}

The rhizome is not only a vivacious plant that regains roots and survives in the most desolate soil but it is also a tuber which can at any time throw a stem and connect with another plant thus producing a plant that does not resemble none of the original plants. Gilles Deleuze and Félix Guattari write in their introduction to Rhizome that "unlike trees or their roots, the rhizome connects any point with any another point, and any of its features do not necessarily reflect traits of the same nature, it involves regimes of very different signs and even states of non-signs” (Deleuze \& Guattari, 1976, p. 61) [my translation] ${ }^{4}$.

In Crossing the Mangrove, the father Loulou Lameaulnes got married to a French woman Aurélie Dugazon, who gave him three sons. Notwithstanding this connection, he also maintained a relationship with his maid Rosalie Sorane, a Negress who gave him a daughter Mira before dying in childbirth. Following the deaths of his wife Aurélie and of his mistress Rosalie, Loulou went to St Martin to ask for the hand of Dinah, a rich daughter of half-Dutch settlers. Dinah herself is the child of a youthful love between her Dutch mother and a Vietnamese student she met in Amsterdam when she was studying pharmacy there. When pregnant, Dinah's mother returned to her wealthy family in St Martin until she was married to a prosperous trader, a widower with five dependent children. Dinah shares the same misfortune being married to Loulou, a widower with three no-good sons and a dependent daughter. Those elements highlight the fact that in the West Indies, the genealogies are branched at different points/strata but also de-territorialized and form a kind of network. As Deleuze and Guattari put it: "The rhizome is made only of lines: lines of segmentarity, of stratification, as dimensions but also a line of flight or de-territorialization as maximum dimensions, according to which multiplicity are metamorphosed by changing nature. Such lines, or lineaments, will not be confused with tree-like lines which are only links between points and positions” (Deleuze \& Guattari, 1976, p. 62) [my translation] $]^{5}$. Such a union as that of Dinah and Loulou

\footnotetext{
3 “Bientôt, ce sera l’Acte Unique Européen et je vendrai mes fleurs jusqu'en Angleterre. Oui, mes fleurs fleuriront la table de la reine d'Angleterre. Her Majesty the Queen. J'ai déjà mon slogan: 'Les fleurs ont leur Paradis sur Terre: La Pépinière Lameaulnes”' (Condé, 1989, p. 109).

4 "A la différence des arbres ou de leurs racines, le rhizome connecte un point quelconque avec un autre point quelconque, et chacun de ses traits ne renvoit pas nécessairement à des traits de même nature, il met en jeu des régimes de signes très différents et même des états de non-signes” (Deleuze \& Guattari, 1976, p. 61).

5 “Le rhizome n’est fait que de lignes: lignes de segmentarité, de stratifications, comme dimensions, mais aussi ligne de fuite ou de déterritorialisation comme dimension maximale, d'après laquelle en la suivant la multiplicité se métamorphose en changeant de nature. On ne confondra pas de telles lignes, ou linéaments, avec les lignées de type arborescent qui sont seulement des liaisons entre points et positions” (Deleuze \& Guattari, 1976, p. 62).
} 
Lameaulnes, which requires such a de-territorialization, does not imply a union based solely on capital or a more important social position. On the contrary, it is a personal expansion, a cartography, which is at the origin of this union: “a conquest, a capture, a transplantation” (Deleuze \& Guattari, 1976, p. 62) [my translation] ${ }^{6}$ to use Deleuze's and Guattari's words. Although Dinah's stepfather reflects upon the prosperity of Loulou Lameaulnes and Dinah's mother sees in this future union of her daughter with Loulou, Lameaulnes' need to have a wife to raise his children, Dinah does not listen to her mother and only sees in her future husband "his dreamy brown eyes" (Condé, 1989, p. 108) [my translation] ${ }^{7}$ and the promise of joy.

The short story The Mixed Country (MC) depicts how Belle Suréna, a laundress of Fort-Pilot, is already in 1869, a strong independent woman who wants to take charge of her life without the help of men. She absolutely does not follow the model imposed by society at that time. Maryse Condé tells us that "At that time, the majority of women used to attract the favors of a man well off... [as] the only way to ascend the social ladder..., Belle breaks with this tradition" (Condé, 1985, p. 9) [my translation] $]^{8}$. She aroused the passion of a well-known politician, a socialist Negro but wanted to keep her independence. "We saw her refusing to leave Bas du Bourg for La Folie, as Jean Hilaire proposed, she refused to give up her job, refused rings, bracelets, pendants, chokers, Caribbean baskets." (Condé, 1985, p. 9) [my translation] ${ }^{9}$. Although her lover is crazy and extravagant at all of her obstacles, she suddenly leaves him to go and help her sister in Kali, South America, companion of a Lebanese merchant who made to her sister six sons and four daughters. Belle does not like the hypocrisy of the bourgeois in Fort-Pilot who have legal families and in addition, black mistresses on the side. Belle does her soul searching and realizes that she is not really in love with Jean Hilarius. She dreams of a passionate relationship that would set her afire and that would reduce her to ashes. Her escape towards South America is not a project of seeking wealth, but a "non-centered expansion, without a general, without an organizing memory... only defined by a circulation of states” (Deleuze \& Guattari, 1976, p. 62) [my translation] ${ }^{10}$.

It is in a romantic mood of seeking true love and wanting to help her sister that she steals to her rescue. And on her arrival in Kali, she experiences the passion she has dreamt of when she sees her sister's partner waiting for her on the gangway. Then, the Lebanese man wants to put an end to this guilty love with Belle by giving her to his Bolivian-born storekeeper Carlos Martinez. Belle has a daughter from him, Pourméra, for whom she will have no affection. But it was not until the death of her sister Sandrine and the remarriage of the Lebanese merchant with a young Italian girl that she took the road back to Fort-Pilot with her daughter Pourméra in her hand, fifteen years later. At the death of Belle, Pourméra follows in the footsteps of her mother, Belle, and learns to be independent. She learnt to sow and to embroider at the Sisters of Charity, and when she left her apprenticeship, she opened a very prosperous notions store and lived alone and free for most of her youth. It was at the age of forty that she lived together with Abelardo, a Creole man of Spanish origin, whom she loved passionately although he drank up all the profits of the day and ruined her. Abelardo was unstable, abandoned Pourméra who was pregnant with his

\footnotetext{
6 “une conquête, une capture, une piqûre” (Deleuze \& Guattari, 1976, p. 62).

7 “ses yeux bruns rêveurs” (Condé, 1989, p. 108).

8 “Alors qu’à cette époque, la majorité des femmes s'attiraient les faveurs d'un homme bien nanti... [comme] seul moyen d'ascension sociale..., Belle rompt avec cette tradition” (Condé, 1985, p. 9).

9 “On la vit refuser de quitter le Bas du Bourg pour la Folie, comme Jean Hilaire le lui proposait, refuser de renoncer à son métier, refusait bagues, bracelets, pendentifs, colliers choux, paniers caraïbes” (Condé, 1985, p. 9).

10 “une expansion acentrée, sans Général, sans mémoire organisatrice... uniquement définie par une circulation d’états” (Deleuze \& Guattari, 1976, p. 62).
} 
child. When Albelardo left her, Pourméra could no longer find in her the strength to fill up the void left by her lover with her daughter Berthe. She became mad and screamed her pain like a wolf howls to death and she had to be interned at the psychiatric hospital Les Baumettes.

\section{Rhizomic Flow Goes in All Directions/Need of Interconnectivity of Caribbean People}

The different previous elements enlight the failed attempts at the stratification of a family by Belle and Pourméra. These remarkable women failed because they wanted to imitate the traditional relationship in-between man and woman, with a flow of love going from the woman to the man only, whereas the rhizome is not amenable to any structural or generative model and has a flow of life that goes in all directions. The relation of a rhizome with others always lays in performance, in-becoming and assumes a relationship in which each individual gives his own self and exchanges in all directions. At the other end of the spectrum, the arborescent relationship goes from one point (source) to another point, in a single direction and it is genetic and always returns to the same model of relationship, endlessly reproducible. On the contrary, the rhizome must be related to everything and everyone. There is an increase in the relationship with everyone as portrayed in the lives of Belle and Pourméra. Both these women enjoyed opulence in their commercial contacts with the whole society, but lost it when they were made the only relationship to a man and dependent on this man if not economically at least emotionally. In their relationship, they were the Source, the ones who gave themselves and gave all of their wealth and who havefinally broken away from this abusive contact/exchange. Deleuze and Guattari advocate a two-way relationship by their explanation of the relation of the wasp and the orchid, the relation of two existences, one animal and the other vegetal, completely heterogeneous as those of man and woman. They assert that in a relationship, there must be a two-way exchange. In the example of the wasp and the orchid, Deleuze and Guattari show this harmonious relationship as they describe that the orchid colors the wasp's features on its petals to guide it to its pollen and that the bee is colored with the pollen of the orchid to help obtain a successful fertilization and hybridization.

\section{Refusal of Seeing the Interconnectivity of Caribbean People: Abusive Relationships}

Berthe's astonishing development in multiple adoption families asserts to the richness of this contact with one another. Berthe, who was abandoned by her mad mother, will find love in a first adoption family consisting of Martha-black eye, a friend of her mother and husband Marius, a cabinetmaker. After leaving Martha and Marius for economic reasons, she moved to another family with no connection with her mother, the landowner family Aubrun. There, she will be well educated and will study in high school. She will be considered as one of them and will believe herself of the same class, showing no compassion or connection with the ragged black peasants that she will see doing a hunger strike at church. But she will fall in love with the son Aubrun, Antoine, with whom she will have a child. This is the crime that will cause her to be rejected from the Aubrun family with her newborn son, named after his father, Antoine. Berthe's rejection from the Aubrun family is even more monstrous and comical as the Aubrun themselves were a mixed family. At the time of the abolition of slavery in 1848, the ancestor béké of the Aubrun, Jean Maheu de la Folie, was intelligent enough to marry his children to the rising class of the mulattoes to remain rich on the island. The Maheu family accepted this creolization in action, for profit, but out of principle, out of love for the peoples on the island. The proof is that when the mulatto son Antoine Aubrun wanted to marry Berthe, his mulatto mother, Altagras, immediately opposed this marriage and 
expelled Berthe pregnant with her son's baby from the family. The problem with Berthe as with all her women relatives before her, is her desire to fix her inter-racial relationship with a blood bond and to give an heir to the mulatto family while "the rhizome must be uprooted from its biological context and transplanted into a cultural context only” (Deleuze \& Guattari, 1976, p. 62) [my translation] $]^{11}$.

Berthe then returns to Martha and Marius located in Port Mahault, where she raises her son Antoine peacefully. She meets a marine carpenter specialized in small boats, Jean Larose, with whom she establishes a stable relationship. However, everything changes when Jean loses his job, because of the progress and conversion of fishermen to outboard engines. This economical change turned him into a drunkard man who beated his companion Berthe. Then Berthe had to leave for Fort-Pilot for the happiness of her child Antoine and she found a job as an accountant in a library in Fort-Pilot. Antoine, now a teenager, learns that his father's family rejected him at birth and he suffers from this separation. He also learns that his half-crazy father has become a respected painter throughout the world. He screams his pain by making friends with the son of a rich landowner Didier Réhat, who also protests against the actions of his father who has enriched himself by buying cheap agricultural properties from his neighbors following the fall of the sugar industry. A "double becoming" between these two teenagers is created echoing Deleuze's and Guattari's words. The rich son colors himself with the injustice that the rich/white/mullattoes impose on the poor black population. While poor Antoine colors himself with the dignity of the rich son (dignity he would have had if his natural father Antoine had recognized him at his birth) and socializes with Didier.

\section{Effort to Reinstate the Co-existence of the Whites, Blacks and the Mulattos in Guadeloupe}

Both Antoine and Didier, seeking justice and social equality, will join the PLO (Popular Welfare Organization) and participate in the "Bloody October days riots". Their revolutionary actions demonstrate how Didier and Antoine's ideas correlate with their actions. They want to fight the hypocrisy of theirmulatto fathers who preached equality between social classes and marriages between classes, but who only applied this principle when it was profitable to them. Through this fight against their father's hypocrisy, Antoine and Didier sought to destroy the latent re-imposition of the model of colonialism and its law of profit and domination of one class over the other.

\section{Failure of the Co-existence in the Caribbean of the 1980s}

Unfortunately, this friendship between Didier and Antoine is not going to continue. When Didier learns of the death of his father by one of the rulers of the PLO and when he sees his friend Antoine covet his sister during holidays spent together at his secondary property on the touristy island of goats, he will regain consciousness of the superiority of his birth (race) over Antoine and will banish Antoine from his life. Although Didier failed in the end to act according to his ideologies, one understands by his prevarications that the identity of a person is not a given genetic datum but that it derives from a personal construction and a choice of orientations between several heterogeneous things and therefore is an event, an individuation.

In these novels, Maryse Condé shows us that the Caribbean in the 1980s is a chaotic place where people have not yet realized that their families have been so amalgamated with one another that it is impossible and even

11 “Le rhizome doit être déraciné du contexte biologique et repiqué dans le contexte culturel uniquement” (Deleuze \& Guattari, 1976, p. 62). 
comical to talk of an alleged superiority of an individual /family over another. In return, people cannot detach themselves from their binary ancestral ideologies and not see their families as white or Black. Oddly, they cannot see that they are members of the same Creolized people, all having as much white and black blood in their veins.

\section{In-becoming state of creolity in the Caribbean}

This new realization of a common creolity is at the basis of the formation of a new identity, culture and literature. Instead of seeing one's self” in opposition to "the other”, it is important to realize that we are all part of a "we”. Bernabé, Chamoiseau and Confiant write in their book Eloge de la Créolité (In Praise of Creolity): "Creolity is the diffracted but reconstructed world, a maelstrom of signified in a single significant: a totality" (Bernabé, Chamoiseau, Confiant, 1989/1993, p. 27) [my translation] ${ }^{12}$. All the cultures of the world are related to one another, are diffracted as a kaleidoscopic totality without possession or domination of a specific culture over the others. To do this, one must go beyond the notion of race and be active to emancipate oneself from his dependence on this notion promoted for centuries by colonialism. This is what Bernabé, Chamoiseau and Confiant recommend in their definition of creolity through the terms of "transactional" and "interactional": "Creolity is the interactional or transactional aggregate of the Caribbean, European, African, Asian and Levantine cultural elements, that the yoke of History had united on the same soil” (Bernabé, Chamoiseau, Confiant, 1989/1993, p. 26) [my translation $]^{13}$. But while in American society, this melting pot of different races manages to homogenize the population, the Caribbean society claims to keep this heterogeneity in itself.

Glissant sculpts the metaphor that has become the true image of Creolity by saying that "Creolity is our primal soup and our original chaos and our mangrove of virtualities” (Bernabé, Chamoiseau, Confiant, 1989/1993, p. 28) [my translation] ${ }^{14}$. Referring to the original chaos, the Caribbean is understood as the place where heterogeneous people have amalgamated and is now impossibleto find the pure origins of these different peoples, to return to the source. This place of the West Indies is equally perceived as a new place in-becoming, a piece of land where this project of a Creole society is in-becoming, does not yet exist and will perpetually be in-becoming. It will also perpetually require that every one acts on to oneself in diversity and see the other also as a reflection of this diversity.

\section{Interconnectivity: The Mangrove Prevents Erosion/the Caribbean People Prevent Extremism}

This biological phenomenon of creolity has its vegetal counterpart in the metaphor of "the mangrove" that Maryse Condé uses in the title of her novel Crossing the Mangrove.

Juliane Tauchnitz gives a definition of the mangrove in her book La Créolité dans le Contexte International et Postcolonial du Métissage et de l'Hybridité (Creolity in the International and Postcolonial Context of Mixing and Hybridity). She writes:

From a cultural point of view, we are dealing with a phenomenon which embodies what l'Eloge (In Praise) means by Creolity: the mangrove is a plant which occupies an in-between space because it grows on the shores between land and sea, half in the water and half on land. It is no longer possible to locate a single plant, to find the origin since its roots

\footnotetext{
12 “La Créolité c’est le monde diffracté mais recomposé, un maëlstrom de signifiés dans un seul signifiant: une Totalité” (Bernabé, Chamoiseau, Confiant, 1989/1993, p. 27).

13 "La Créolité est l'agrégat interactionnel ou transactionnel des éléments culturels caraïbes, européens, africains, asiatiques et levantins, que le joug de l’Histoire a réunis sur le même sol”. (Bernabé, Chamoiseau, Confiant, 1989/1993, p. 26).

14 "La Créolité est notre soupe primitive et notre chaos originel et notre mangrove de virtualités" (Bernabé, Chamoiseau, Confiant, 1989/1993, p. 28).
} 
intertwine with those of other mangroves thus creating a stable and impenetrable network that also serves as a concrete metaphor for the rhizome of Deleuze and Guattari as well as to the notion of Glissant’s “opacity”. (Tauchnitz, 2014, p. 95) [my translation $]^{15}$

Thanks to the interweaving of mangrove with other mangroves and the impossibility of retracing the original roots of one mangrove, this plant not only protects the West Indies of the erosion of its banks but also of the erosion that another colonial program would have on the society by claiming the superiority of one root/origin on the other. Juliane Tauchnitz depicts the mangrove in the following way: "It designates the only plant but also a whole complex ecosystem: from an ecological point of view these plants present mainly on the tropical littorals protect a big part of the shores against erosion and help in that way to safeguard the life of many zoological species. These marshes of mangroves help maintaining such islands as the West Indian islands”. (Tauchnitz, 2014, p. 94) [my translation].

\section{Rhizomic Structure of the Novel: Equality of Interpretations of Author, Narrator, Characters and Reader}

In Condé's narratives analyzed throughout this article, the rhizomic structure prevails. There is no superiority of thought by an author-genitor of the book. In the novel Traversée de la Mangrove (Crossing the Mangrove), the story is told by all the characters from the village of Rivière au Sel who gather at Francis Sancher's wake and who give their point of view on the latter's identity. Moses, the postman, compares this old friend to a tree "massive, high as a mahogany" (Condé, 1989, p. 31) at the side of which, he, puny, thought to take umbrage and regain the respect of the community. The other men were suspicious of the body: Francis was maybe a "makoumé", a homosexual. It was not understood that he had relationships with the two youngest women of the country Mira and Vilma and had given them children. But it was when he is not seen working to cut down trees like the locals but rather seen sitting at a writer's table, that people imagined shady origins in relation to his income: "Francis Sancher reportedly would have killed a man in his own country and would have pocketed the stock. He would have been a hard drug trafficker... a weapon's trafficker supplying the guerillas of Latin America” (Condé, 1989, p. 39) [my translation] ${ }^{16}$. A range of identities is given to Sancher. This comes in opposition with the dichotomy of Plato's tree, which makes a word like "tree" correspond to a tree concept, or to Saussure's significant/signified dichotomy. Sancher's name encompasses a range of signifieds. At the image of a rhizomic structure, Sancher has no roots and ramifies in all directions. What is important is not the identity of Sancher, the hero of the novel, but the point of view that every inhabitant of Rivière au Sel, although auxiliary characters, have read. As in the rhizomic structure, there is no vertical hierarchy where the main hero of the novel or the subject of the novel is more important than the characters or contributing subjects. There are, on the contrary, transverse connections; each character passes through Sancher and gives him a different direction and at the same time prints a new direction of meaning to the novel. Despite the variety of points of view, each speaker's

\footnotetext{
15 “Du point de vue culturel, nous avons affaire à un phénomène qui incarne ce que l’Eloge entend par Créolité: la mangrove est une plante qui occupe un espace de l'entre-deux car elle pousse sur les rives entre terre et mer, à moitié dans l'eau, à moitié sur terre. Il n'est de plus pas possible de localiser une seule plante, de trouver l'origine puisque ses racines s'entrelacent avec celles d'autres mangroves créant ainsi un réseau stable et impénétrable qui sert également de métaphore concrète au rhizome de Deleuze et Guattari ainsi qu’à la notion d’opacité de Glissant” (Tauchnitz, 2014, p. 95).

16 "Francis Sancher aurait tué un homme dans son pays et empoché le magot. Ce serait un trafiquant de drogue dure... un trafiquant d'armes ravitaillant les guérillas de l’Amérique latine...” (Condé, 1989, p. 39).
} 
utterance brings new light on Sancher. Moses is reminded of Sancher's first declaration of solidity of constitution and admits that during the night Sancher was a man haunted by evil spirits, like "a beast struck at the bottom of a hole to die!” (Condé, 1989, p. 30) [my translation] ${ }^{17}$. Even Sancher does not know who he is. He only thinks that like his ancestors, he will die at the age of fifty in punishment for a crime committed in the family. A crime he has tried all his life to repair by his service for the oppressed of the earth, but he is not taken seriously in his wanderings of spirit.

He, as the main character of the novel is clueless about himself, his origins, his life. No one's voice is superior to the other and the last speaker who discovered that Sancher was the descendent of a béké who committed crimes on the island is Xantippe, the fool of the village. His wanderings in the forest led him to discover the remains of the slaves whom the Sancher ancestor Béké had put to death. He said:

I know his whole story. It is on the crutched roots of these mapos lele trees that the puddle of my blood has dried for a crime has been committed here, in this very spot, in very ancient times. A horrible crime, the odor has stuffed the nostrils of the Good God. I know where the tortured people are buried. I discovered their graves under the moss and the lichen. I scratched the earth, whitewashes conches shells and every night in the serene, I come here to kneel to two knees. Noone has pierced this secret, buried in oblivion. Not even he who runs like a crazy horse, sniffing the wind sniffing the air. Every time I meet him, the look in my eyes burn his eyes and he lowers his head, because this crime is his. His. He can sleep quiet though, squashing women, planting sons, I will not do anything to him, the time of the vengeance has passed. (Condé, 1989, p. 259) [my translation] ${ }^{18}$.

In The Mixed Country, the narrator is a doctor from Saint Hyacinth Hospital in Fort-Pilot, very fond of genealogy, who not recognizing the surname of two bodies of the son and mother brought to him after a bomb attack, decides to find the identity of this family. Although he is the main narrator, he does not fail to say his human faillibility and begins his narrative by this sentence: "Why am I telling you this story, perhaps entirely false, recreated to the strength of my imagination and the patience of my research?” (Condé, 1985, p. 6) [my translation $]^{19}$. He does not establish himself as the author of these human lives but as a witness of their history that he has searched patiently in books and land registers. "It took me two years to reconstruct the facts, to reconnect these scattered threads. I confess that I had to invent, plug a lot of holes. Yet, I feel satisfied. I have not betrayed them, Berthe and her son” (Condé, 1985, p. 7) [my translation] ${ }^{20}$. The genealogy of Surena is to be made and this doctor makes this reconstitution of existence by crossing the lives of Antoine and Berthe Suréna back to their original source of Belle Suréna. Very often the doctor says he finds himself at the crossing of life and does not know which way to go, but Antoine, though dead, seems to weigh with all his weight of his past existence and it makes him understand which direction he has followed.

\footnotetext{
17 “une bête aux abois venue se terrer au fond d’un trou pour mourir!” (Condé, 1989, p. 30).

18 “Je connais toute son histoire. C’est sur les racines en béquilles de ces mapous lélé que la flaque de mon sang a séché. Car un crime s'est commis ici, ici même dans des temps très anciens. Crime horrible dont l'odeur a empuanti les narines du Bon Dieu. Je sais où sont enterrés les suppliciés. J'ai découvert leurs tombes sous la mousse et le lichen. J'ai gratté la terre, blanchi des conques de lambi et chaque soir dans le serein je viens là m'agenouiller à deux genoux. Personne n'a percé ce secret, enseveli dans l'oubli. Même pas lui qui court comme un cheval fou, flairant le vent, humant l'air. A chaque fois que je le rencontre, le regard de mes yeux brûle les siens et il baisse la tête, car ce crime est le sien. Le sien. Il peut dormir tranquille cependant, engrosser des femmes, planter des fils, je ne lui ferai rien, le temps de la vengenance est passé” (Condé, 1989, p. 259).

19 "Pourquoi est-ce que je vous raconte cette histoire, peut-être entièrement fausse, recréée à la force de mon imagination et à la patience de mes recherches?” (Condé, 1985, p. 6).

20 “J’ai mis deux ans à reconstituer les faits, à renouer ces fils épars. Je l'avoue, j’ai dû inventer, boucher pas mal de trous. Pourtant, je m’estime satisfait. Je ne les ai pas trahis, Berthe et son fils” (Condé, 1985, p. 7).
} 


\section{Rhizomic Structure of the Novel: Reader Needs to Be Active in the Creation of the Meaning of the Text}

These works by Maryse Condé are similar to a rhizome in the sense that the reading plot is not indicated by the author like in more traditional works. The doctor says that he has had to fill in the voids with his own judgment and his imagination. This means of using the imagination is like a line of flight indicated by Deleuze and Guattari, "an escape line forcing the stratas to explode, to break the roots and to operate new connections" (Deleuze \& Guattari, 1976, p. 44) [my translation] ${ }^{21}$. Moreover, the reader has to disentangle by himself the different bits of stories left by the characters. He deconstructs the text imposed by the author or the society of the author and releases the character/slave who was imprisoned in this text or social context of the author. This is what the doctor of The Mixed Country does, who tries to understand why Antoine Surena had wanted to bond with the sister of his friend Didier Réhat. To achieve this purpose, he deconstructs the text, he refuses to read what the society of the time understands like financial interest, and he says that Antoine, like his mother and women ancestors before him, was moved by passion in all his life choices:

It is possible to make of Antoine an intriguing young man who enters a bourgeois family to defile the virgins, thereby avenging the wrong done to his mother and to himself. This sounds ridiculous to me. He was probably sincerely in love, a victim of this fascination exercised by the wealthy classes over others. (Condé, 1985, p. 72) [my translation] ${ }^{22}$

\section{Rhizomic Structure Sets the Characters Free and the Reader Free of Any Prejudices}

This method of reading lets the reader free to make his own interpretation choices, and not be influenced by the author or the society of the author. We see here that the society of the author Maryse Condé, a francophone society, would have given the blame to the Black Antoine against the White Réhat. The reader, represented by the doctor, lends on the contrary an attentive ear to Antoine's words/ills. The reader like the doctor in this short story wants to be impartial in his interpretation of the story. The judgment of Antoine's fate involves him personally, puts him in play and he does not want to fail at his task. By espousing the cause of the blacks, the reader like the doctor is transformed outside of any established model. He dares annihilate the reprobation that the French-speaking society of the author launches on the violent movements of these young people; he understands their revolt and the fact that these young people have only the choice between dying for a better future or dying in engaging into the (French) army. He says of that time:

It was after the explosion of the Emmelynck Tower that housed the Independent Radio. Four boys and girls who dreamt of a future without masters or servants, without rich or poor, without békés, metros, niggers, or mulattos, had been buried under tons of cement, iron, glass and plastic... Antoine was out... gone back out after long discussions on the doorstep, while behind the wall of the cinder block Yellow man sang: "They say that in the army/ girls are fine..." (Condé, 1985, pp. 77-78) [my translation] $]^{23}$

\section{Transformation of the Reader As a Passer and Hope of a More Interconnected Society}

By embracing Antoine's cause, the reader/doctor become like Antoine an anti-hero who distances himself from his society to preach liberty. The reader becomes like Antoine, a reader-navigator-browser who jumps into

\footnotetext{
21 “... une ligne de fuite permettant de faire éclater les strates, de romper les racines et d’opérer des connections nouvelles” (Deleuze \& Guattari, 1976, p. 44).

22 “Il est possible de faire d'Antoine un jeune intriguant s'introduisant dans une famille bourgeoise pour en souiller les vierges, vengeant ainsi le tort fait à sa mère et à lui-même. Cela me semble ridicule. Il fut sans doute sincèrement amoureux, victime de cette fascination qu'exercent les classes aisées sur les autres” (Condé, 1985, p. 72).

23 “They say that in the army/The girls are very fine..." (Condé, 1985, pp. 77-78).
} 
the other, the nowhere, the in-becoming world of alliance with the heterogeneous at the same time as "a bomb exploded in the premises of the main independent organization of our country, killing a young man who was in charge of it, no doubt to ensure permanence" (Condé, 1985, p. 6) ${ }^{24}$. The reader no longer recognizes himself. He differentiates himself from who he was before, differentiates from his group, opens himself to others and says: "Some wanted to see in his death the just punishment of the gods... As for me, that is not how I see it. Martyr of a cause that will eventually triumph.” (Condé, 1985, p. 80) [my translation] ${ }^{25}$.

The reader becomes a passer-by. He thus observes that the message that the author has put forward in a particular historical and social context re-contextualizes itself in his time and society and grows in eternal value.

\section{Conclusion}

This article laid the emphasis on the rhizome as the best suited symbol to describe the identity of the characters in Condé's narratives. Indeed, their identity can be segmented and transplanted into another area but theystill sprout roots in that new environment and therefore survive as the Caribbean people have survived the break with their African families after slavery, along with the de-territorialization and re-territorialization and have prospered in the West Indies. Similarly to the mangrove, the rhizome is also a plant that intermingles with other plants and grows in all directions implying that the flow of life goes in all directions, contrary to the symbol of the tree where the flow of life follows the unique direction of the root to the foliage. It is the best symbol to describe the equality of all the Caribbean people from a racial as well as a social point of view.

Moreover, the rhizome invades also the very structure of the book and imposes an equal voice on all the participants in the novel whether it is the author, the characters, the narrator or reader. The book is not written by an author-genitor of the text who exploits the characters to say his story and who traces an ideology to the reader that the latter will have to swallow. The characters themselves, give their viewpoint on the topic of the text, and the reader through their remarks, finds himself attracted to understand and solve their enigmas. The performativity of the relations of the author, reader and the characters propel them into a state of in-becoming where each comes out of the frames ofhis present state and throws himself into the other, the heterogeneous.

\section{References}

Bernabé, J., Chamoiseau, P., \& Confiant, R. (1989/1993). Eloge de la Créolité (In Praise of Creolity). Paris: Gallimard.

Bhabha, H. K. (1994). The location of culture. London/New York: Routledge.

Césaire, A. (1983). Cahier d'un Retour au pays Natal (Notebook of a Return to my Native Land). Paris: Présence Africaine.

Césaire, A. (2004). Discours sur le colonialisme. Suivi de Discours sur la Négritude (Discourse on Colonialism. Followed by Discourse on Negritude). Paris: Présence Africaine.

Condé, M. (1985). Pays Mêlé (The Mixed Country). Paris: Collection Monde Noir Poche, Hatier.

Condé, M. (1989). La Traversée de la Mangrove (Crossing the Mangrove). Paris: Mercure de France.

Condé, M. (1999). Le Coeur à rire et à pleurer: Souvenirs de mon enfance (The Heart to Laugh and to Cry). Paris: Robert Laffont. Deleuze, G., \& Guattari, F. (1976). Rhizome, Introduction. Paris: Les Editions de Minuit.

Fanon, F. (1952). Peau noire et masques blancs (Black Skin White Masks). Paris: Seuil.

Glissant, E. (1996). Introduction à une poétique du divers (Introduction to a Poetics of Diversity). Paris: Gallimard.

Miller, C. L. (2008). The French atlantic triangle: Literature and culture of the slave trade. Durham (NC): Duke University Press.

24 “... une bombe explosait dans les locaux de la principale organisation indépendantiste de notre pays, tuant net un jeune homme qui s’y trouvait chargé sans doute d’assurer la permanence” (Condé, 1985, p. 6).

25 “Certains ont voulu voir dans sa mort le juste châtiment des Dieux... Moi, ce n’est pas ainsi que je le vois. Martyr d’une cause qui finira bien par triompher” (Condé, 1985, p. 80). 
Poinsot, M., \& Treiber, N. (1953). Entretien avec Maryse Condé: A l'occasion de la parutionde son dernier roman, La Vie sans Fards (Interview of Maryse Condé: In honor of the publication of her last novel, Life without makeup). Retrieved from: https://hommes-migrations.revues.org/

Tauchnitz, J. (2014). La Créolité dans le Contexte International et Postcolonial du Métissage et de l'Hybridité (Creolity in the International and Postcolonial Context of Metissage and Hybridity). Paris: L'Harmattan. 